\title{
Board Certification
}

National Cancer Institute

\section{Source}

National Cancer Institute. Board Certification. NCI Thesaurus. Code C19602.

The process by which a person is tested and approved to practice in a specialty field, especially medicine, after successfully completing the requirements of a board of specialists in that field. 